保跓物理 Vol.3(1968)

海洋放射能污染の防護

市川竜資 ${ }^{*}$

( 1968 年 8 月 12 日受理)

Protection Against Radioactive Contamination of Sea

By Ryushi ICHIKAWA

\begin{abstract}
In view of the rapid increase of nuclear energy facilities such as power plants, fuel-reprocessing plants and so forth, the safe control of the disposal of radioactive wastes into the sea has been and will be of great concern in the world. The present paper deals with the following matters; (1) historical background information of radioactive contamination of the sea due to the past military use of atomic energy, (2) natural and artificial radioactivity in the sea, (3) general features of the behaviour of radioactive nuclides in marine environment, (4) safe management of coastal discharge of radioactive liquid wastes, (5) disposal of solid radioactive wastes into deep sea bottom, and (6) problem on international control of radioactivity release in marine environment.
\end{abstract}

\section{1. 歴史的回碩}

海洋の人工放射能污染がはじ的て我々の注目を集めた のは, 1954 年3月1日マーシャル群島ビキ二䃆礁の東 方約 $150 \mathrm{~km}$ のとてろて死の灰に被災したマクロ延縺漁 船「第 5 福竜丸」の事件でる。てれは同日ビキ二環礁 上て行左われた米国の $15 \times$ メトン水爆実験に上り生じた

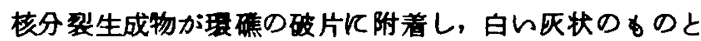
丸って降下したののに被嫘した為起った。放射性核分 裂片は勿論㕕い水域に散布され，日本の漁港に陸提げさ れるマグロカシキ等に放射能の検知されるののか続出

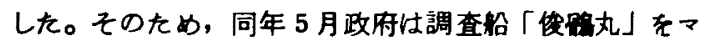
一シ+几群島一需の水城に派逗して海水, 海産生物等 の放射能污染状況調查したが，海洋の放射能污染は相 当に高くかつ仏籍囲に亘っており，6月21日，ビキ二 西方 $450 \mathrm{~km}$ 亿て探取した海水に $91,000 \mathrm{dpm} / \boldsymbol{l}$ の ベー＼cjkstart放射能を覞测した。海水污染仕当時てすマリアナ 群島附近にまて及んており, 涌場としては, 北赤道海流 （メバ千の楱息域）が污染が最高く, 次いて赤道反流 (キワダ,クロカシキの棲息城)が污染しているととが 判明した。翌1955 年に行々われた米国巡視船ク二ー号 の調査に上れはての污染は 3 月頃すてにフィリビン沖の 海域に移動しており，同年夏の日・米・加協同の北太平
洋調查の際行各われた海水, ブランクトンの放射能測定 からこの污染恃その頃日本の大平洋岸冲合にまて移動し ているととがわかった。

しかしなから，核実験に上る海の污染は実少規模る がらての時上り 8 年前にすてに始まっていた。すなわち

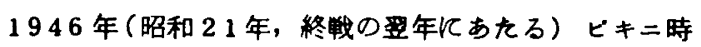
間て 7 月 1 日早朝，B29 加投下された原爆（約 20 キ ロトン)はビキ二礁内に集結した標的嚂隊の上空 180 mてさくれつした。 22 隻の監船には戦監ネバががその

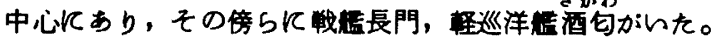
酒匂はこのとき坎上し，翼朝沈んだといわれ，長門は大 破したが沈主ず，ついて行なわれた25日の水中実験 (海面下 $30 \mathrm{~m}$ て器叱) におらて沈んだ。この 2 度の核 実駼恃，その前年 7月ニューメキシコ州 Alamogordo て行玑九初の原爆実駼, 同 8 月軍事目的飞使用さ れた広島，長崎一の投下に次ぐ 4 度目の核爆発てあって，

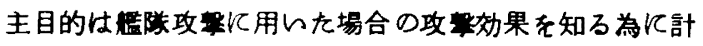
画されたものてある。ての時病院船に乗って参加したワ シントン大学の放射楾生態学研究所（当時は応用水産学 研究所と称していた)のグルーブはビキ二䃄礁内及ひ周

* 放射腺医学総合研究所 National Institute of 


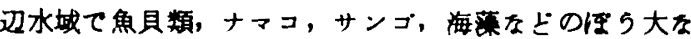
数にの任る試料老探取し，その放射能湖定に従事した。 これけ人工放射能に上る海洋生物污染の調査研究の曼初 のわのと言らてとがてるる。

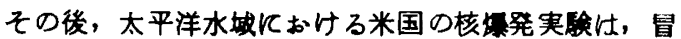
頭にのべた 1954 年のビキニ水爆実騟にいたるまて，ビ キ二西方約 $300 \mathrm{~km}$ にあるエニエトック锿礁におして 1948 年 3 回, 1951 年 4 回, 1952 年 2 回, 之繰返 し行なわれた。てれらはいなれす高空爆発てはないから， 生成した放射性の核分裂生成物は殆んどその海域に散布 され，海水や生物を污染したことが前出のワシントン大 学のクルーブにより, 詳しく調査報告されている。

ての上5K人工放射能に上る海の污染か，何与の国際

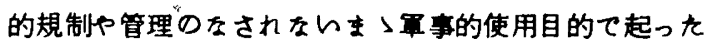
ことけ，人類が益々海洋をその福祉の為に利用する方向 に向っている祭儿甚だ不幸なととと云わさるを得台的。

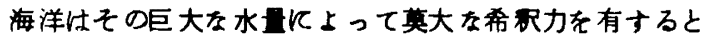
㤌言气，增大寸る核エネルギーの利用に上り必然的に。

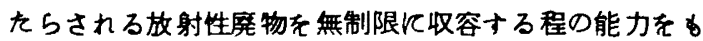
つわけてけなく，人類の将来における海洋资源の有効在 利用の為に適正规制と管理が求められることは当然て ある。以下章を追って現在の海洋放射能の水準や治岸て の放射性庭淮の放出，哚海への固体廃来物の投来等に関 寸万現況中問題点后上を整理し，海洋の放射能污染の防 表炕つけて考充てみ上5。

\section{2 海の放射能とその起源}

現在，海の中に存在寸る放射性物留恃，その起源から，

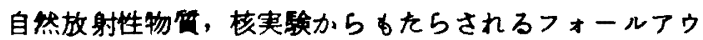
卜，お上び局所的てはあるが原子力施設から放出され る放射性庰液中固体廃来物の投来に上り海中に入った人

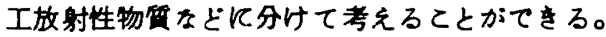

海水の自然放射能柱として ${ }^{40} \mathrm{~K}$ 几るるのの，約 $300 \mathrm{PCi} / \ell$ 含まれている。 ${ }^{87} \mathrm{Rb}$ とウラン系列仙共 㶧々 $3 \mathrm{P} \mathrm{Ci} / \ell$ て、大洋表属水の自然の ${ }^{3} \mathrm{H}$ 忙 $0.6 \sim 3$

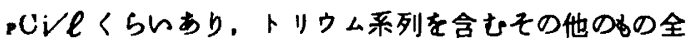

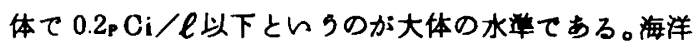
生物に含まれる自然放射能る同样にその殆どが“0 Kて あり, 海萧て $1 \sim 15 \mathrm{p} \mathrm{Ci} / \mathrm{g}$, 魚肉 $\tau 015 \sim 3.4 \mathrm{p} \mathrm{Ci} / \mathrm{g}$

(共飞生重量当り)といら值が得られている。

てれに対し，人工放射能としてすへてての海域に检出さ れるるの湖 ${ }^{90} \mathrm{Sr},{ }^{187} \mathrm{Cs}$ がある。核実験が大型化し， かつ高空て行名われる5に后って，その核分裂生成物 は大部分成屏图に注入されてきた。そしてそれが $1 〜 5$

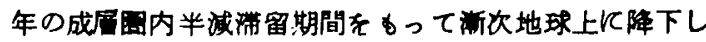
てくる。降下の㜊速は实符の場所と高度に上って相进す る。こらして人工放射性核程が全海城にもたらされたの てあるか，半娍期の短かり核程恰出不能にまて娍衰し たのて現在検知されるのは ${ }^{80} \mathrm{Sr},{ }^{137} \mathrm{Os}$ の核程力㱠 どの場合てある。てれらフォールフウトに由来する核程 の海水中浱度は北半球㣂南半球儿低的。乙九は従来 の核鼠発実験が主に北半球て行なわれ ${ }^{80} \mathrm{Sr},{ }^{137} \mathrm{Cs}$ の 降下率が大さいからでる。なお，バチック海や黑海 の上5に大陸に囲まれた海は外洋上り数倍高いが，てれ

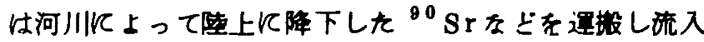
ナるからてある。ての現象は河川の流入する沿岸や湾て

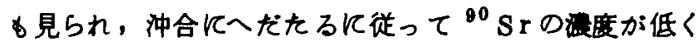
るることが䚈祭されている。また，海洋表届に降下した

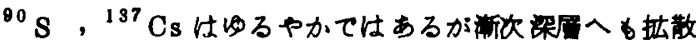

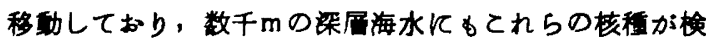
知される。第1罒に日本近海における海近の海水中の浱 度の垂直分布示打。

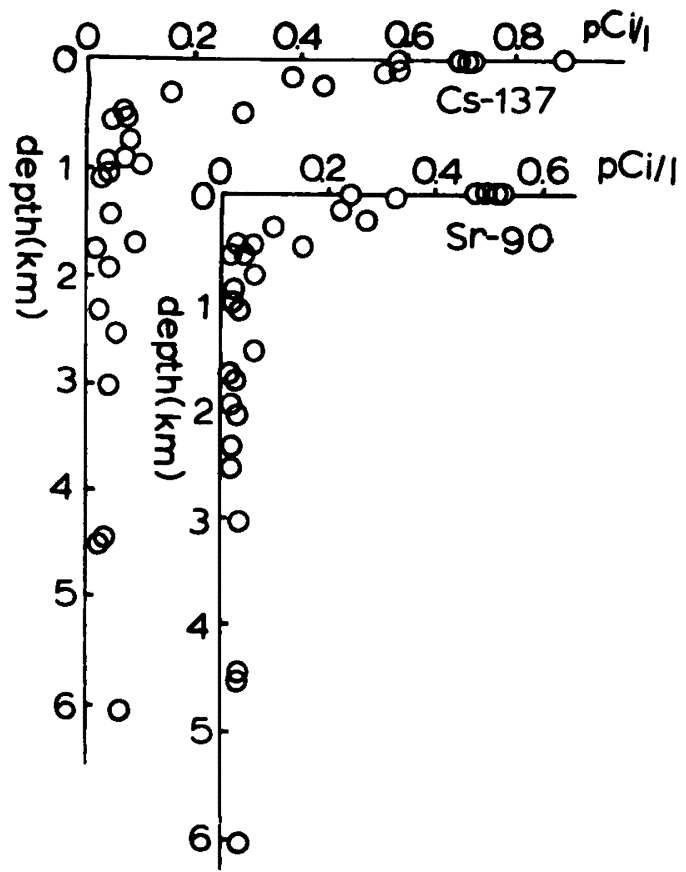

第1図 1963，1964年になける日本近 海の海水中 ${ }^{911} \mathrm{Sr},{ }^{187} \mathrm{Cs}$ 漫度 の重直分布 (長屋他 1965 )

この上5に厸く海水中に含まれる ${ }^{911} \mathrm{Sr},{ }^{197} \mathrm{Cs}$ 性当 然食用海産生物にとり入れられて人間の食事加ら拱取さ 


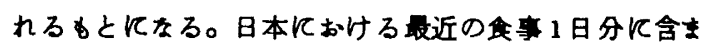
れる ${ }^{00} \mathrm{Sr}$ 壮10〜 $20 \mathrm{PCi}$ 任ごすり, ${ }^{187} \mathrm{Cs}$ は 20 〜 $30 \mathrm{PCi}$ 程度てある。そのらち海産魚介類からとり入 れられる核種の每が食事全体の5ちのどれくらん占め ているかを示したのが第 2 四てある。との值は 1966 年
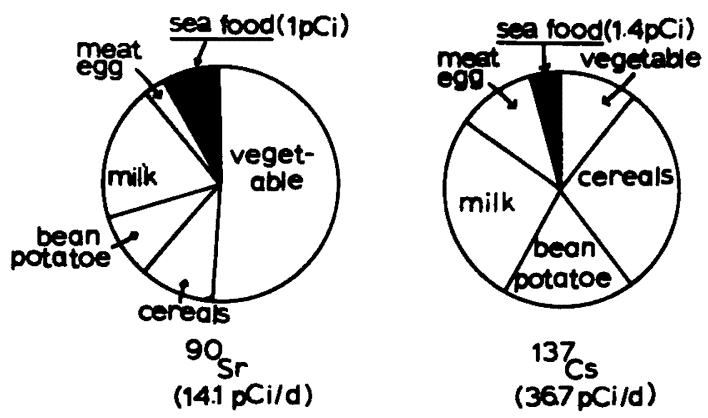

第 2 因 ${ }^{90} \mathrm{Sr},{ }^{137} \mathrm{Cs}$ の 1 日当りの提取贯 の全品別内訳, 1966 年 6 月東京試 料の例（佐伯他 1967）

6 月東京における分析値でり，類 $4229 ，$ いる類 859 , 豆類 359 , 牛乳 1809 , 卵 309 , 肉 309 , 魚介 類 $75 \mathrm{~g}$, 莱莱類 $144 \mathrm{~g}$, 根莱類 969 者 1 日分とした場 合のののて，個人個人の食性や経日棸化は勿論ある。し 加し大ざっはとは、， ${ }^{90} \mathrm{Sr},{ }^{137} \mathrm{Cs}$ 共に全掫取量の数心 一セントの寄与が海産物火由来するのつといらととがて さる。一般燅産物の方か海産物上りフォールアウトに 上る污染受け易的。他や河のフナคコイの ${ }^{90} \mathrm{Sr}$, ${ }^{197} \mathrm{Cs}$ は海の魚上りナっと高的度走示す。乙れは海の

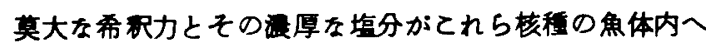
の移老相当程度防いているからてある。

以上は全世界規模の污染てあるが，局所的なるのし

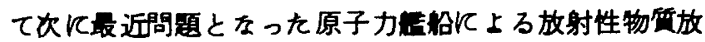
出につんて少しふれてみ上5。米国海軍の原子力監は 1966 年 1 月現在て 59 隻が運航しており，その5ち56 复が替水篮てある。妒の一次命却水中に出現与る放射性 物夏はんわり corrosion products と称し,パイフ 加ら水中に登出した微量の物梊が炬の中性子に上り放射 化されたののて, ${ }^{61} \mathrm{Cr},{ }^{60} \mathrm{Co},{ }^{69} \mathrm{Fe},{ }^{54} \mathrm{Mn},{ }^{66} \mathrm{Ni}$,

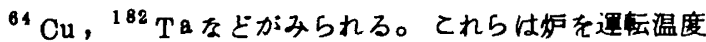

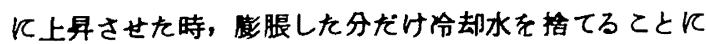
上って外界に出る。外炕出埸合恃净化系老通すてとは もちろんてある。米海軍ては掵却水中のてれら放射性核 種の組成, 半诚期の長短, 許容レペルの上下なとの関係
から， ${ }^{80} \mathrm{Co}$ 无っとも問題となる核種とし，廃液中の 長半诚期核程全部 ${ }^{60} \mathrm{Co}$ とみなして管理子万方式をと っている。そしててれら原子力艦残のオーバーホールを 行なったり操業基地になっている多数の港において海水， 海底土を定期的に採取測定している。第1表に示したの

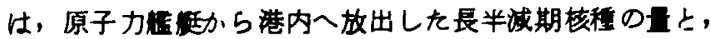

表 1 米国の原子力潜水艦基地における放射能 調查結果（米海軍省 1966）

\begin{tabular}{|c|c|c|c|}
\hline \multirow[b]{2}{*}{ 更港 } & \multirow{2}{*}{$\begin{array}{c}1961 \text { 1 } \\
1965 \text { 年 } \\
\text { の間港内 } \\
\text { 放出した豆 } \\
(キ ュ リ ー)\end{array}$} & \multicolumn{2}{|c|}{ 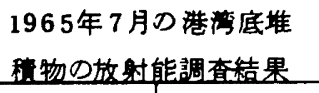 } \\
\hline & & 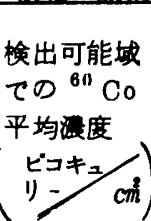 & $\begin{array}{l}\text { 港流底 }{ }^{60} \mathrm{Co} \\
\text { 全の推定值 } \\
(キ ュ リ ー)\end{array}$ \\
\hline $\begin{array}{c}\text { ホーツマス } \\
\left(\begin{array}{c}\text { ニーシンブ } \\
\text { シャー }\end{array}\right)\end{array}$ & 0.48 & 検出不能 & 同左 \\
\hline 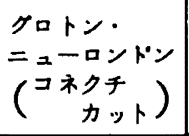 & 7.18 & 190 & 0.19 \\
\hline 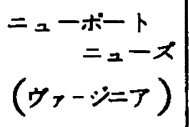 & 2.31 & 検出不能 & 同 \\
\hline $\begin{array}{l}\text { チャールストン } \\
\left(\begin{array}{l}\text { サウス } \\
\text { カライナ }\end{array}\right)\end{array}$ & 1.19 & 検出不能 & 同左 \\
\hline $\begin{array}{l}\text { イーーーク } \\
(ウ,-\dot{*}=了)\end{array}$ & 1.17 & 検出不能 & 同 左 \\
\hline $\begin{array}{c}\text { サンティェゴ } \\
\left(\begin{array}{c}\text { カリフォ } \\
n=ア\end{array}\right)\end{array}$ & 0.99 & 30 & 0.003 \\
\hline $\begin{array}{c}\text { Vall le jo } \\
\left(\begin{array}{c}カ リ フ \\
ル ニ ア\end{array}\right)\end{array}$ & 0.03 & 10 & 0.001 \\
\hline $\begin{array}{l}\text { ハーールハーパー } \\
\left(\begin{array}{lll}\text { ハワ } & 1\end{array}\right)\end{array}$ & 3.20 & 10 & 0.03 \\
\hline $\begin{array}{l}\text { アブラハーバ- } \\
\text { (カム島 })\end{array}$ & 0.01 & 検出不能 & 同 左 \\
\hline
\end{tabular}




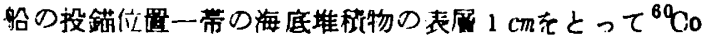

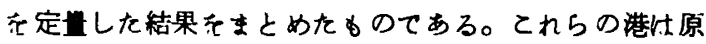
替の基地になっているとてろてあって，外国の港の场合

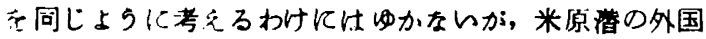
基地てあるスコットラント・のHoly Loch て ${ }^{611}$ Co が湾 底土に検出されたととがある。

一方, 原子力の平和利用飞伴なって生ずる放射性廃物

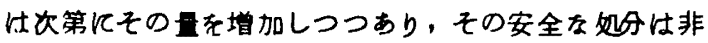

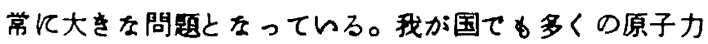
発電所か洋著々建設またけ計画されつつあり，核然料再 処理工场すその建設か決定されている。従ってそれらか ら生する液体お上び固体つ放射性廃物つ処理処分につん て壮我か国の自然的か上び社会的諸条件を考成に入れて

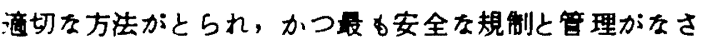
れかげならない。一般飞放射性廃物を処分寸万時の原理

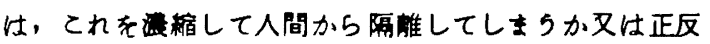

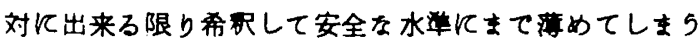
かとい52つの方法からなっている。岩塩採堀の廃坑に 投入する方法恃前者に属し, 治岸海城への放出は後者に

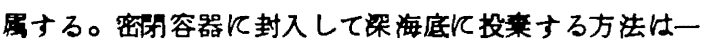

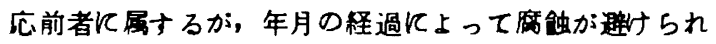

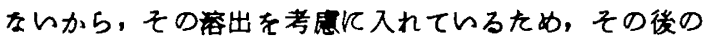
扗散について、後者の原理をす組合せているすのと言ら ことかてきる。

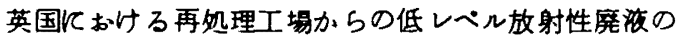
浻海放出は1952 年からはじまっており, 米国ての固体 放射性麾物（密封容器入）の海底への投来 61951 年頃 ナてにはしまっている。我が国で放射性同位元素使 用寸る事菜所等杜数多くあり，それらの廃物は日本放射 性同位元秦協会か一括して策荷眝藏し，小規模てはある が東京外に投來したすのわある。

\section{3. 海中における放射性核程の举的}

フォールアウトや放射性廃液の形て海中に入った放射

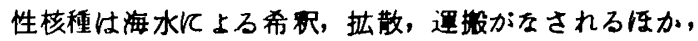

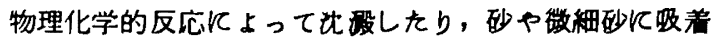
して沈下堆稓されるすのすある。従って長寿命の核稞の 海城ての地城的拡加り老検知する為には, 海底堆程物老

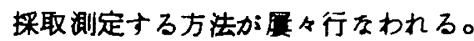

一方，数千 $\mathrm{m}$ の梁海底に投来する固体㲥来物は，年月 と共に容器か偶伷され，内容物の容出考えるいわけに

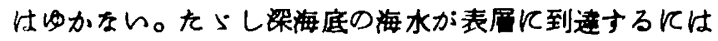
長的月老要し, 数 10 年五いし数 100 年の期間者見込 むととがてろから，その間の放射性核種の物理的減衰

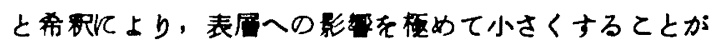
てさる。

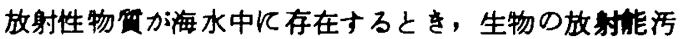
染が起る。生物体一の放射性核種の䔄皘される程度壮生 物の種類，体の部位および核種の種類るどによって相连 するが，海水中核種浱度とその中長期間生息する生物 体の核種浱度との間には或程度定量的関俰者求䚮てと

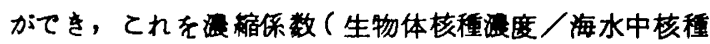
漫度)をむってあらわす。第2 表はそれをとりまとめて 示したののてある。この俰数は，海水中核種漫度が与え られをとを，各食用水産生物の污染度を推算するのに便

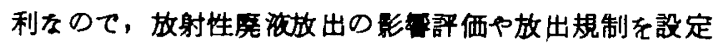
する場合などに上く用いられる。たらしてれらの値は, 污染海水中性物が長期間生息し，外界浱度と生体内浱 度とが平衙涚した時のレべルを表わすりのてあって， 短期間の海水污染て，生物污染度が河水隼几なるのて

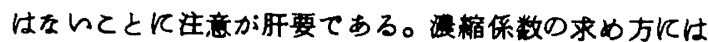

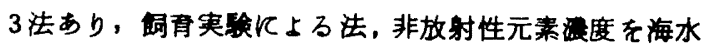

表 2. 海産生物の放射性核種浱樎係数(市川,プライアン,ボリカルポフ)

\begin{tabular}{|c|c|c|c|c|c|c|}
\hline 生物核種 & ${ }^{90} \mathrm{Sr}$ & ${ }^{137} \mathrm{Cs}$ & ${ }^{65} \mathrm{Zn}$ & ${ }^{80} \mathrm{Co}$ & ${ }^{84} \mathrm{Mn}$ & ${ }^{86} \mathrm{Fe}$ \\
\hline 魚 & $0.1 \sim 0.3$ & $10 \sim 20$ & $3,00 \propto \sim 4000$ & $20 \sim 80$ & $100 \sim 300$ & $500 \sim 3,000$ \\
\hline 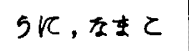 & $1 \sim 2$ & 10 & 1,000 & 200 & 200 & $10,000 \sim 80,000$ \\
\hline えび,かに & $0.1 \sim 1$ & $10 \sim 30$ & $1,000 \sim 4000$ & 4,000 & 800 & $1,000 \sim 4,000$ \\
\hline 貝 & $0.1 \sim 0.2$ & 10 & $10,000 \sim 40,000$ & $100 \sim 200$ & $1,000 \sim 10,000$ & $8,000 \sim 15,000$ \\
\hline 海 & $1 \sim 10$ & $1 \sim 10$ & $100 \sim 1,000$ & $30 \sim 60$ & $1,000 \sim 2000$ & $2,000 \sim 5,000$ \\
\hline
\end{tabular}

註：值は可食部生重量に対する。の。 
と生物との用て比较する法, お上びフォールアゥトや原 子力施設から放出された放射性廃做に上って現実污染 されている水城の海水と生物とを比较する方法とが用い

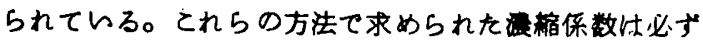
しす一致せず，目々かなりの相速が睍察されるが，その 原因には種々あり，例气ば垔鉊，铁，コバルトよにて 姛育実駼に上る檤が非放射性元素浱度で得られた值上り 相当下题るのは, 海水と生物との間の平街状㮩が達成さ れるまての期間が長く，姛青実験がその期间を十分カハ 一し難らととに由来している。また，表にはあげている 々か， ${ }^{108} \mathrm{Ru},{ }^{95} \mathrm{Zr}-{ }^{95} \mathrm{Nb},{ }^{144} \mathrm{Ce}$ な゙の上5K海

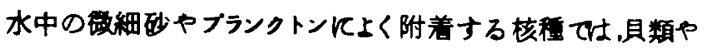

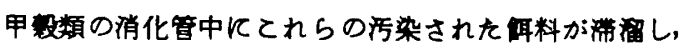

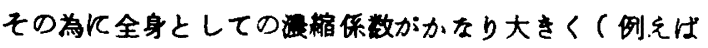
$10^{3}$ ていと）覞察されることが現埸つまりゥィンズケー ル工埥治岸城等加ら報告されてんるのに対し，铜育実験

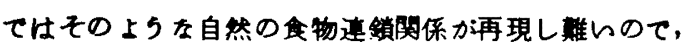
污染佴料の消化管内带留の寄与がなく，従って得られる 制保数ははるかに低くるるのがふつらてある。ての上 5 な睍点から，筋肉部だけを食用とするか全身支用と

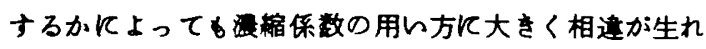
ろこと6注意せかばならなん。

次に，この上5な生物体内人の放射性核種の蓄積が の上5経路から行なわれるかとい5問䞻がある。一般

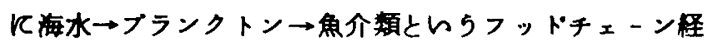
路と, 海水から直接魚介類にェラゃ体表から吸収される 経路とがあって, 常に両者の寄与があり, そのいうれが 大きいかは，核種，生物，䍗境条件に上って左右される が，くわしい定旦的情報は未だ不足てある。乙の問題に つんてはストロンチっムにつんて罡る多く情報があり, エラその他からの所䚴直接吸收が伖に由来する寄与上り

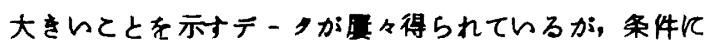

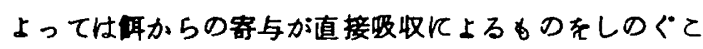
とああり得るとんら情報す報告されている。

放射性ストロンチっム取扱から场合には，港縮係数 上り年 $\mathrm{Sr}-\mathrm{Ca}$ 差別比 ( $\mathrm{Sr}-\mathrm{Ca}$ Observed Ratio) 老用いる方が便利古場合が屋々ある。魚の場合のそれは, （魚体の Sr/Ca比）：(海水中 $\mathrm{Sr} / \mathrm{Ca}$ 比）の比て求

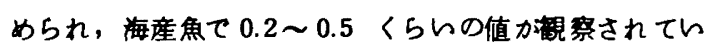
乃。乙の現象は, 外界のSrとCaが生物体にとり込ま れるとを，SrがCa凡対して差別されるてと意味し ており, 従ってふつ5 Sr-Ca 差別比は 1 より小さん。 この比老用いると, 海水中の ${ }^{90} \mathrm{Sr}$ 浱度 ${ }^{90} \mathrm{Sr} / \mathrm{Ca}$ の 值 )加魚その他の生物の ${ }^{90} \mathrm{Sr}$ 度が推算で，てれ

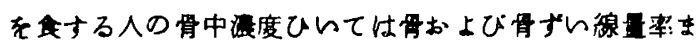
て逴結して考察するととが可能てある。海産生物つSr$\mathrm{Ca}$ 差別比飞例外的な値をもつものに壮 アカンサリア

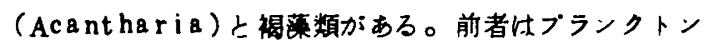
性の原生生物て、硫酸ストロンチゥムててきている骨片

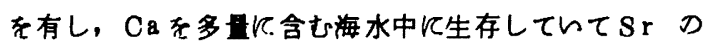

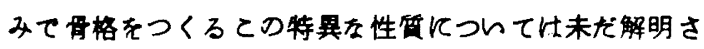
れているい。偻者は $2 \sim 3$ くらんのSr-Ca差別比在

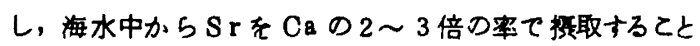

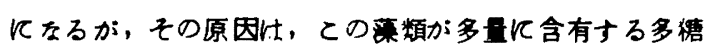
類てあるてルギン酸が，Srにかるりつ親和性老持つて

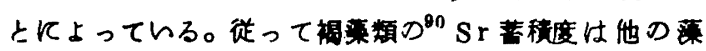
類上りかなり高いが，フルギン酸に結合したストロンチ っムは人体の消化管内ての消化吸収が悪いととが雅かめ られている。

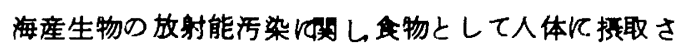
れる事柄と全く異なった分野がす5一つある。すをわち， 魚卵が放射線被瞵老与け，飞の発生に何等かの悪影老 受けるか上らかとんら問題てある。ソ揤における研究 に上れば,ボラ,カレイ,カククチイワシ,アジよ゙す 卵や射化直後の雅魚につき ${ }^{911} \mathrm{Sr},{ }^{9 n} \mathrm{Y},{ }^{144} \mathrm{Ce},{ }^{182} \mathrm{Cs}$, ${ }^{95} \mathrm{Zr}$, ${ }^{106} \mathrm{Ru}$ の浱䈹老調べた結果, 特飞 ${ }^{80} \mathrm{Y}{ }^{144} \mathrm{Ce}$ ，

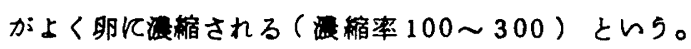
これは恐らく表面への附着に上る质染と考えられるか， それに上り卵が放射線照射を5け，かなりつ低瀑度の ${ }^{90} \mathrm{Sr}-{ }^{80} \mathrm{Y}$ 海水て卵発生に影加検知されるとん5。

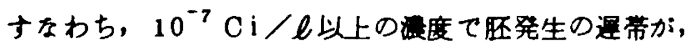
$10^{-8} \mathrm{Ci} / \mathrm{l}$ 以上て肧の死亡率の上年と前期稚魚の体長 の小型化か， $10^{-8} \mathrm{Ci} / \boldsymbol{l}$ 以上で交胚期での細胞分裂能 力つ低下ゃ染色体異常つ增加お上び掫佴闰始期ての稚魚 死亡率の增加が看取されるとい5。更飞 $10^{-10} \sim 10^{-11}$

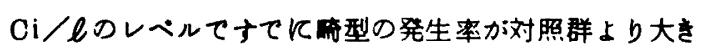
くなり，搌度の高くなるに従って畸型発生率も高くなる ことがみられたと報告されている。しかしながら，英国 における ${ }^{911} \mathrm{Sr}-{ }^{911} \mathrm{Y}$ 海水ての魚卵の発生実跧や低レべ

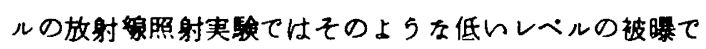

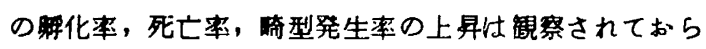
ナ゙，末だ明確な定目的情報忙不十分と言らことがてる。

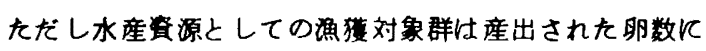
比して枚めて小さんるのであり, 特に卵, 稚魚の期間に 多くの桭境要因が関与して，或程度の数量しか漁㙏対象

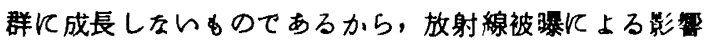
は相当に大きいすのでなければ現実の水産凅源量にはひ びかんてあろら。 


\section{4. 放的性廃源沿岸放出の規制と管理}

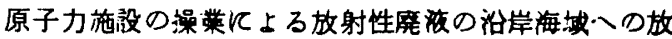
出処分海し，一般住民の放射線被樭の防鿁の大めの施 策は，大をく分けて，廃依放出の规制とその影需を受け る渨境の安全管理とい5互に密着した両面から考えるこ とがでる。第 3 図にその一般的方式を规制か上び管理 の両面を対応させて示す。まず規制面ては，個々の施設 (核然料再処理工场，原子力発雪所等）に対し，廃湤放 出に制限を課さればならない。これには，与えられた線 田限度の筑囲内て，その地城の種っの条件下てどの程度 の放出が可能であかの推算を行ない，これに十分な安 全案をみこむととと，その施設の提莱のために臤低必要 る放出率に抑える処毛が必要である。この場合に最す大 きく支配する因子は，故出事一被暴線量の成係について の定头的情報てあって，放出核程組成，その海域中ての 抬散希㹞過程，金用海産生物队涌具・砂等の污染度，住 民のそれら食用生物掫取式，涌貝损作時間，海浜作業時 間等のハララークに上ってをまるすのてある。従って施 設の設詳にあたって十分にてれらの情報を検即しておか なければならない。てれに対応して管理面ては, 当然, 当該環境のモニクリンクが行なわれ，㻓境の放射能水輩 ひんてけ住民の被嫘息が十分安全側に保たれているこ とを確認せかばならない。珢境放射能レベルの定常的監
視にあたっては，環境物夏の放射性核種湿度なとに対す る尺度として，珢境放射能管理指栖（Derived Working Limit，略してDWLとい5）とてす言えるものを用い ると便利なととがあろ5。なぜならば，桭境放射能污染 に上る人体の被照の防落のるとになっているすのは决定

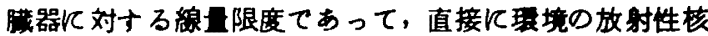
種港度て示されるすのてはない。一方, 喂境モ二クリン クのデーク後者の形て求められ，てれを人体防学の立 場から評価するに湶胃限度とサーペイデークとの仲だ ちをするすのが必要てあり，てのために作られたのが のDWLてある。DWLは特定の场所と条件のもとにおん $\tau$ ，染気，食用生物，無生物等の放射性核種流度（時に

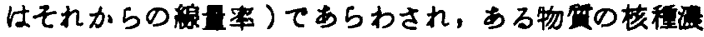
度がその场合のDWL值以下でれば，それに上る線量

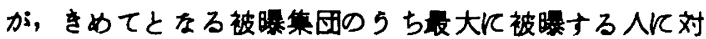
してす与えられた線量限度を决して越えないてとを保証 ナるといら性筫のすのである。要するにモニタリングテ 一クをてれとつを合せて, 住民の被睩の安全度の確認を 行ならためのるのてある。モニタリング結果は放出実綡 と組合せて解析し，操莱前に行なった影評価に対する

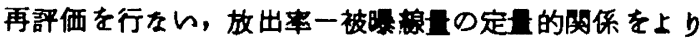
正しく把握することに年するべきてある。その上らな観 点から，英仏などは，新しい施設に対し最初数年間は安

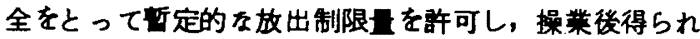

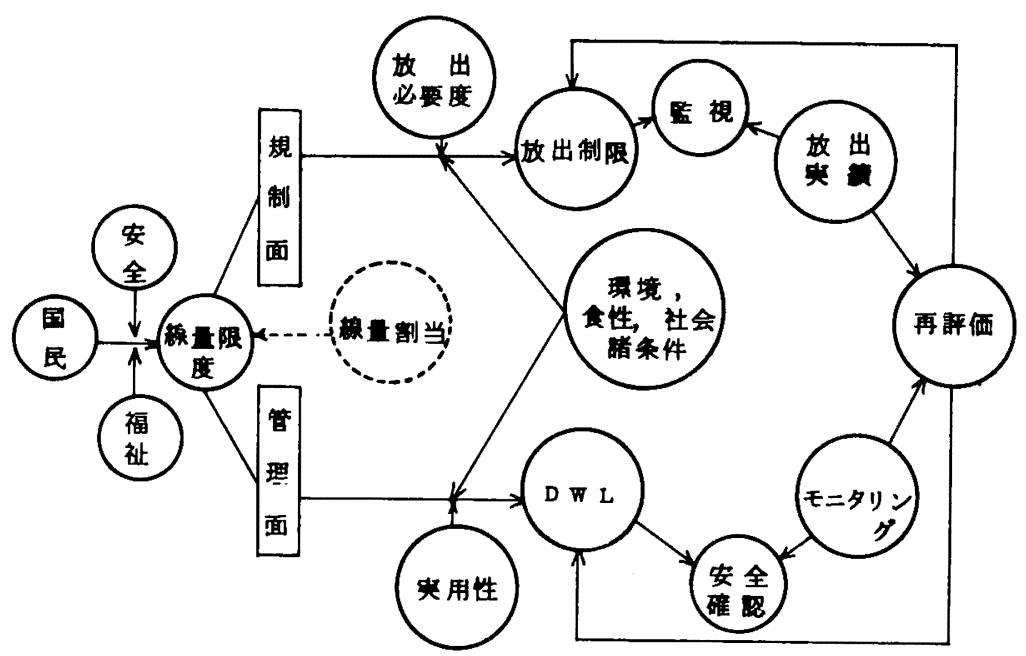

第 3 図海域への放射性廃湤放出の規制 と桭境安全管理の一般的方式 
た調查赫果の解析を十分に行ない，必要あれは許可放出 罡の改訂が可能でる上らな方式をとっている。

放出規制と珢境管理の基本になる線贯限度恃国自身て さめるすのてあり，JCRPの訲告内容が広く探用され ている。たらし，摆境の放射能污染に上る公衆の放射線 被擼の可能性は単に海城への低レペル放射性廃湤放出に 上るすののみとは限らない。原子力産業の荓発進展に伴 なん，公采への可能な放射線源は陸（施設からの空中， 论水八の放出, 地中埋没等) と海（治岸放出, 深海投来, 原子力船々上）とにわたって程々の场合が考气得る。従 って，海城放出の規制を行ならにあたっては，与、らられ た線五限度の5ちから海城放出の分として幾らかの部分 (例えば1/3とか V/10とか) をあらかじめさんてすら い，その筷囲内て放出を考えるとい5方法をとるか，も

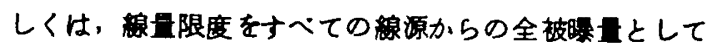
一括して考え，海城放出を規制するに当って与えられた 線些限度を决定して越えない上5え取大放出率を十分下

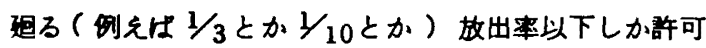
しないとい5方法とが考えられる。インドのBhaba 原子

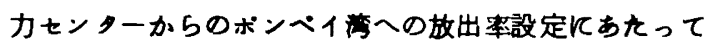
は前者の方式がとられ，ICRPの線限度の $1 / 3$ を基 本にとって规制を行なっている。传者の方式に対しては, 英国のやり方が医医それに近いと考えられる。

以上は，きめてとなる被䁬集団 (critical group) に対

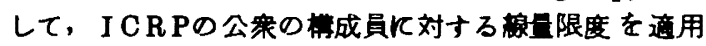

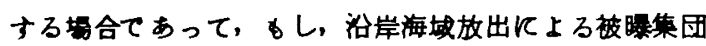
が相当に大きんときは，遗层線量を考国せかばならない ことも有り得るし，さらにそれに伴なって，放射性廃激 放出に网しての进伝被限度の割当てをどのくらん見込 むかとん5問題がててくる。現実の例としては, イント の Bhaba 原子力七ンターからの沿岸放出規制におんて，

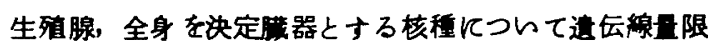
度を用いている例があ。てれはポンべイ地城の全住民 の70\%が魚人口と考えられるととに上っている。他

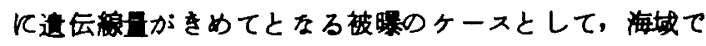
はなんが，英国のアルダマストン，ハーウェル，アマー シ+ムの 3 施設がテームス河に放出しているヶースがあ

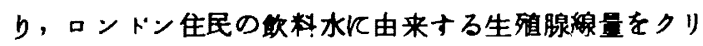
ティカルとしている。

外国における治岸海城への放射性物啠の処分につんて みるル，まず最す瞣高䄳験をつつのは英国てある。 この国における珢境への放射性廃来物の放出は放射性物 啠法 (Radioactive Substance Act) Kよって規制され ており, 同法に上れば，「放射性廃来物の放出古，建設. 自治省と榓水産食栢省とが地方自治体当局に謀問した上
て発給する認可嗪項にしたがってのみ可能てある」とさ

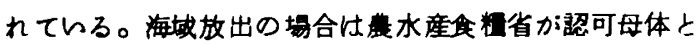
なり，その認可放出目設定にあたって基本となる考え万 は, 「放射性廃来物の管理に関与る白聿1959」に示さ れている次の 3 項目がその要点てある。

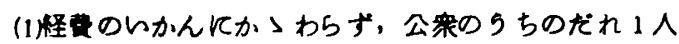
としてICRPの公衆の構成員に対ナる峌告値をとえない ことを保証する（身体的影咋的とうく制限）

(2)释费のいかんKかつわらず，国民全人口が平均被瞵 楾量として1人 30 年1ラトをとえないととを保証する （这伝的影腹にとうく制限）

(3)上記絶対越えられないレペルてあって現実に可能 る限り実際の線量はそれ上りはるかに低く保つ上5にす る。

したがって英国の原子力公社各施設や中央発電庁の原 子力発電所等の認可されている放出制限值は施設毎に相 进し，ウィンメ゙ィール核然料再処理工场が全 $\beta$ 放射能て $75,000 \mathrm{Ci} / 3$ ケ月てあるのに対し多くの発面所にては $200 \mathrm{Ci} /$ 年とんら大差を生んているのは, 主として当 該施設の操業のための最低放出必要度が大きく異なるこ とに起因してらる。ウィンスケール工场の放出制限値は 3 ケ月あたり全 $\beta 75,000 \mathrm{Ci},{ }^{106} \mathrm{Ru} 15,000 \mathrm{Ci}{ }^{80} \mathrm{Sr}$ $7,500 \mathrm{Ci}$, 全 $\alpha 450 \mathrm{Ci}$ (1965 年改訂発効) て, ボル フィラ(紅藻)の ${ }^{106} \mathrm{Ru}$ 污染が放出制限のきめとな っているが，その样子は第 $3 ， 4$ 表に示す 1966 年の放

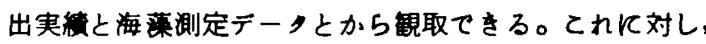
中央発電所 (CEGB) と南スコットランド電力斤 (S SEB) 几所属する原子力発電所の放出制限とそのきめてとなる 被嚗形式は第 5 表のよ5になっており, 実際に放出して らる恃それら制限值上りはるかに小さんとんわれる。

第3表 ウィンズケール工場からアイルラ ント海に放出された放射性物行 (1966 年実嚗)

（英原子力公社 1967 ）

\begin{tabular}{|c|c|c|}
\hline 放射能の種類 & $\begin{array}{l}\text { 3ケ月当りの放出量 } \\
\text { 実 䁲 (平 均) } \\
(\neq=リ-)\end{array}$ & $\begin{array}{l}\text { 放出制限量に対 } \\
\text { ナる割合 }(\not{\phi})\end{array}$ \\
\hline 全ベーク放射能 & 16,392 & 21.9 \\
\hline${ }^{106} \mathrm{Ru}$ & 6,231 & 41.5 \\
\hline${ }^{\theta 0} \mathrm{Sr}$ & 228 & 3.0 \\
\hline${ }^{144} \mathrm{Ce}$ & 1,713 & - \\
\hline 全アルファ放射能 & 146 & 32.5 \\
\hline
\end{tabular}


第 4 表 ウィンズケール工場のある治岸域の海藻の放射能(1966 年)

（英原子力公社 1967）

\begin{tabular}{|c|c|c|c|c|}
\hline 試 & 放射能の種類 & $\begin{array}{l}D \cdot W \cdot L \\
(p C i / g)\end{array}$ & $\begin{array}{l}\text { 平均放射能 } \\
(\mathrm{pCi} / \mathrm{g})\end{array}$ & $\begin{array}{l}\text { DW LK対与 } \\
\text { 万割合 ( } \% \text { ) }\end{array}$ \\
\hline & ${ }^{1116} \mathrm{Ru}$ & 300 & 134.0 & 44.7 \\
\hline 糜液放出管近傍の & ${ }^{95} \mathrm{Zr}$ & 1800 & 10,1 & 0.56 \\
\hline 4 地点て探取した & ${ }^{95} \mathrm{Nb}$ & 3000 & 7.1 & 0.24 \\
\hline \multirow[t]{3}{*}{ 海竜 } & ${ }^{90} \mathrm{Sr}$ & 12 & 0.14 & 1.2 \\
\hline & ${ }^{144} \mathrm{Ce}$ & 300 & 6.4 & 2.1 \\
\hline & ${ }^{106} \mathrm{Ru}$ & 300 & 56.8 & 18.9 \\
\hline 故出管上り遠い4 & ${ }^{98} \mathrm{Zr}$ & 1800 & 6.3 & 0.35 \\
\hline \multirow[t]{3}{*}{ 地点の海湫 } & ${ }^{85} \mathrm{Nb}$ & 3000 & 4.0 & 0.13 \\
\hline & ${ }^{90} \mathrm{Sr}$ & 12 & 0.11 & 0.92 \\
\hline & ${ }^{14} \mathrm{Ce}$ & 300 & 3.4 & 1.1 \\
\hline
\end{tabular}

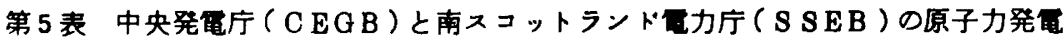
の放出規制（英国婁水産食粗省 1967 ）

\begin{tabular}{|c|c|c|c|c|c|}
\hline 設贯 埸 所 & 出力 (MW) & 完 成 年 & 排水放出場 所 & 放射能放出制限值 & 被暴線些計算の対象 \\
\hline : - ク v 1 & 275 & 1962 年 & 汽水城 & $\mathrm{Ci} /$ 年 & $\begin{array}{l}\text { 外部被軹, } \\
\text { サケ肉の颃取 }\end{array}$ \\
\hline ブラドウエル & 300 & 1962 年 & 汽水域 & $\left\{\begin{array}{cc}50 & \mathrm{Ci} / \text { 年 } \\
{ }^{66} \mathrm{Zn} & 50 \mathrm{i} / \text { 年 }\end{array}\right.$ & カキ肉の提取 \\
\hline $\begin{array}{r}\text { ヒンクレ1 } \\
\text { ホ1 } \\
\end{array}$ & 500 & 1965 年 & 治岸 & $\mathrm{Ci} /$ 年 & 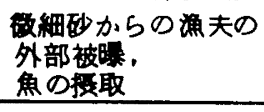 \\
\hline ダンシェネス & 550 & 1966 年 & 治岸 & $200 \mathrm{Ci} /$ 年 & 魚の摄 取 \\
\hline サ1ズェル & 580 & 1966 年 & 沿岸 & $\mathrm{Ci} /$ 年 & 魚の摄取 \\
\hline ハンターストン & 300 & 1964 年 & 治岸 & $200 \mathrm{Ci} /$ 年 & 魚の掫 取 \\
\hline
\end{tabular}

* S S E B

したがって放出水域に活染の検知されるてとは殆どなく， ブラッドゥェル原子力発電所が签料冷却地を象化するの

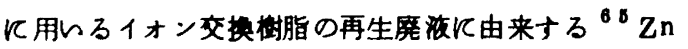
が附近のカキに検知されているてとが例外的なっースて ある。と〉壮河口水城であって，第 4 図に示与上5に放 出口からの距離に上ってカキ肉中の ${ }^{65} \mathrm{Zn}$ 湜度の变化か
上く翼察されている。

1967 年試㗑操莱に入ったフランスの La Hague 核 然料再処理工场は主として仙雷力庁の発管所の使用成然料 の処理を引受けるととになっており，海中に $5 \mathrm{~km}$ にわ たって实出する放出管をるっている。ての施設の放射性

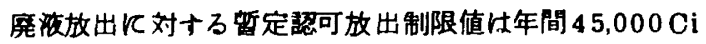




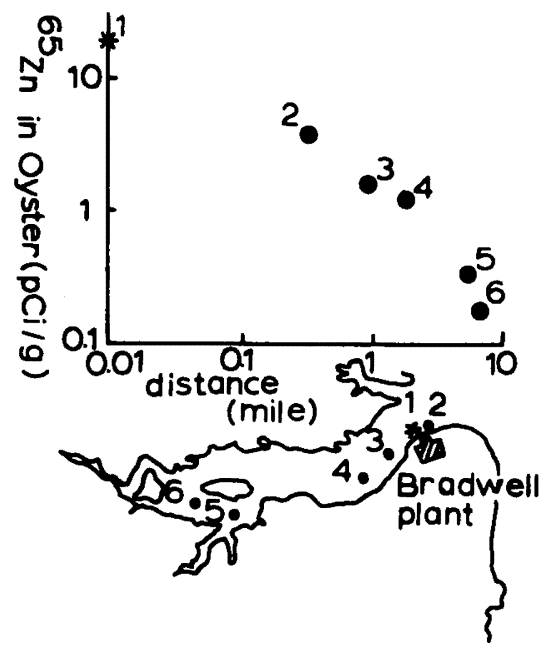

sea

第 4 図 プラドウェル原子力器電所附近の カキ肉中 ${ }^{66} \mathrm{Zn}$ 浱度と放出口か. の医碓に上万变化（Prestn 1966） 米故出口

て，乙の地方の涌村に住む涌夫とその家族につんて年間 1 人 30 K 90 魚の消费をみこむと，上記制限值にて被港 線田は 10 ミリラト以下に推算されるとい5。たらし当 分の間は 4.500 Ci の放出て操莱するととが可能てある としている。

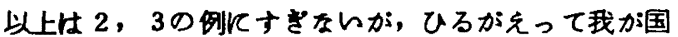
の現状をみるに，英国と同样国土の粡岛国であると同 時に古くから全国の治岸に涌業活功が行古われ，涌村の 発達しているととは他国に類例をみない程でる。ての

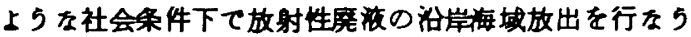
には，本章に述べたよ5な合理的かつ現実的な放出規制 と安全管理かなされ，さらにをめのてまかい行政的処田 が考えられれはならないし，また，その実行のためには てれらのるとになる科学的情報の十分な蓞皘が必要であ る。

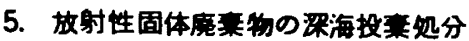

原子力発電の操菜に上って出される使用成のイオン交 换榯脂，スラッシその他の赫廃来物等の取終処分方法と

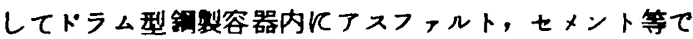
固化を行ったのち，海底に投来するととが我が国て す 検討されている。固体庰莱物の梁海投来処分は米国が大 西，太平両洋に，英国が大西洋にそれぞれ投乗の経験か;
ある。しかし米国け広大国土をるち，地中処分による 人間から隔雄が比端的容易てあるから，怪费と手数のか かる海中投来処分は余り重視されているん上5てある。 乙れに対し我か：国や欧洲諸国の上5に国土の自然的お上 び社会的条件に上って地中処分の困奞なんくつかの国々 ては，梁海投来処分に期待をかければならねいナ5势に ある。そのあらわれとして，フランス，西独，英国， ○ ルギーお上びオランダの5 ケ国は ENEA（欧州原子力機

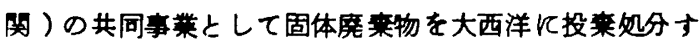
ろととを企画し，1967 年秋その第 1 回投来（試験投來 と称する）を行った。梁海投来した廃来物につんては沿 岸放出の上らな行届いた管理をすることが事実上困睢て あるから，その事前の影解析は十分飞安全側に行なわ れればならなん。この上のな観点から，ENEAの編成 した門家クルーブはこの投来につんて次の上のな方式 て事前試算を行なった。十なわち，(1)廃来物収秋容器は 破壊されすと海底に到達する，(2)容器はおそらく数十年 後に腐钫が始まりその後ゆっくりと数十年の間にわたっ て放射能が外部人客出十る の推定されるが，試算て は全容器が投来後十年て完全に壊れ全放射能が直ちに容 出ナるすのとする，(3)梁居水中に溶出した放射能け一部 は底質に固定されるてあるか，定早的情報が得られたん から試算てはてれがゼロてあるとする，(4)深海底の放射 能が表屋に到迋する時間はかなりの長年月がかつるとさ れているが，てっては生物に上る移功飞の他の影整を考 えて十分安全側にとり，10 年とい5値を用いる，(5)表 首近くるると乱流海流に上って更に希㹞されるてある がこつではれがないのとする，(6)海水から海産食

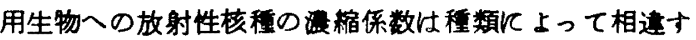
るが，最す大をい值を用いる，(7)公采が食べる海産生物 は放射能の影涫のない水城のすのとの混合になる筈てあ るが, こ〉ては蛋白必要吾を全部この影海城からの生 物てまかなえる值として1日300 gの排取を考えている。

ENEAてはての上5な試算方式て，毎年 $10,000 \mathrm{Ci}$ の投桻の场合そしてその内容に $20 \% の{ }^{60} \mathrm{Co},{ }^{90} \mathrm{Sr}$ ， ${ }^{137} \mathrm{Cs}$ を含むとして，公央の放射能控取はＩＣRP の勧

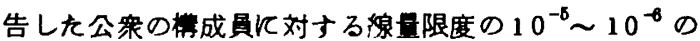
レペルに匹敵するすのにしか過ざないといら結果を得た Łら。

我が国は四面海にかてむれているが，同時に漁場とし ての利用度も高く，梁海投来場所の塄定には事前の十分 現地調査（深海加与の垂直払散，生物の棲息状況等） が必要てあると共に, 投来用容器の耐破壊, 耐腐䶿, 難 溶出性等の工学的試験研究が切化望まれる所以である。 


\section{6. 海洋放的能污染に関する国祭的規制の问题}

海洋への放射性物咓の処分に上る海域污染の可能性に つんては国際機関に上ってい古く上り注目されており，

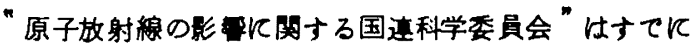
1956 年からこの問題をとりあげ, 1958 年報告の中

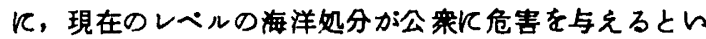
らととはないが，将来には重要な問題とるり得るし，国 際的な劦力と同意が必要てあり，また学にての問題につ

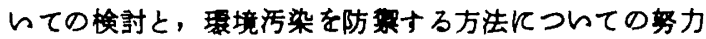
がなされ杍去るいと述へている。

また，1958年 4 月にシューネウて咸かれた“海洋

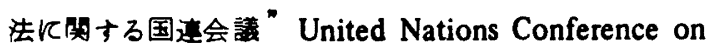
the Law of the Sea 㤌, 元来廃油派上万海洋污染問 題からおてったすのてあるが，放射性物行に上海洋污

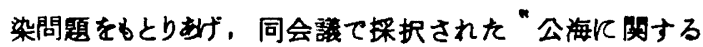
協約" Convention on the High Seas (1958) の第 25 条次次の 5 亿述べえ。

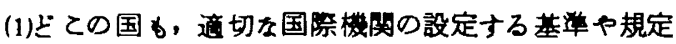

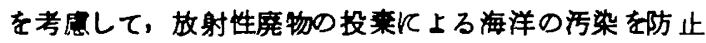
ナる方策をとるべをと。

(2)すへてて国が，放射性物留中他の有害物に上る海洋 とその上の空間の污染を防止する方策をとることにおい て適切国際機関と協力すべさてあること。

また，同会境は，放射性物留に上万公海の污染につん ての决諘を採択し，その公式記录の中に次の上5反述へ てиる。

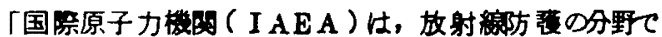

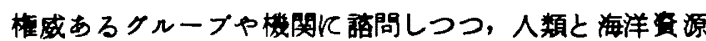

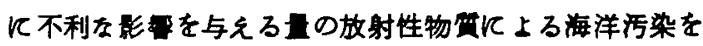
防止する為の，基準を公布したり国察的に受入れられる 規定をつくるてとに上り，各国における海一の放射性物

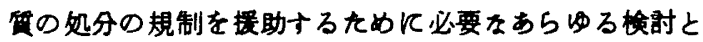
事業を行らべをとと。」

I A EA は， 1958 年, 放射性廃物の海洋処分飞関寸

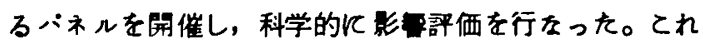
がプリニールンン報告てある。 $\mathrm{JAEA}$ はついて，海洋
処分に関して国際的飞適用しのる規筑を立法化する可能

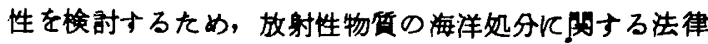
ハシネルを1961年1月上り1963年1月まて4回にわ たって開催した。てれがルンーパネルてある。てのパネ

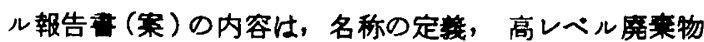
の処分禁止条项 ( 未処理使用济核然料とその化学処理の 分蜼の第 1 段階から生ずる廃物の処分を笔止する），沿 岸水城ての処分条項，各国の処分情報を IA EA 涌告

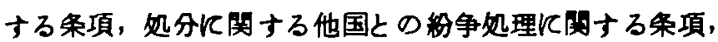
処分几䦎与万国内法規の I AEAへの通告, 海洋処分禁 止につんての条項え上を含んている。しかしながら，て のパネルにおける各国亘門家の間て種々の問存点にて意 見が一致せず，粉争条項につんては，当事国間交涉もし くは拘束力を持九ない中立仲介者のるとに交陟を行るら 方式と，汃りの拘束力をるつ中立仲介者いしくは委員 会を通して交步を行方ら方式とが対立して調整がてをす， 2 案を並記することになった。すた，放射性物保の海洋 処分は人類お上び海洋具源に対して有害てあり，したが ってさへての処分を整止するといの条項寨が少数国から 出され，てれす併世探镍されているといら状況てある。

ての上5反各国間の意見対立が強く反映されている性 質のののてあるため，IAEA理事会の勒告とい5形て 公布され上5とした当初の考えはついに実現されるとと が出来ず， バネルの討論や提案の内容はいまだ陭の目を みていないのが実情てある。

I AEA㤌その後，各加盟国の放射性物啠海洋処分の

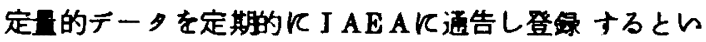
与制度を計画し，各国の劦力を求めて吐足したが，满足 すべき情報の提供がえされずその為に自然消站の形と るっている。

以上の上5K，海洋の放射能污染防設成与万国際的 劦調を実現する努力は未だ実を桔んておらず，各国の国

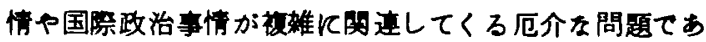
る。しかし，今後る海洋処分の対象となるすのが增加の 一途をたどることは明白であり，何等かの国際的規制の 方策がとられる上5国連か上びその䙳門機関の努力が続 けられるととが強く望まれる。 